\title{
Management and organizational innovation in Brazil: evidence from technology innovation surveys
}

\author{
Daniel Paulino Teixeira Lopes $^{\mathrm{a}}$, Allan Claudius Queiroz Barbosa ${ }^{\mathrm{b} *}$ \\ adaniel.lopes@globo.com, CEPEAD/FACE/UFMG, Brasil \\ b*allan@ufmg.br, CEPEAD/FACE/UFMG, Brasil
}

\begin{abstract}
From a broad perspective on the topic of innovation, considering not only technological innovations in products and processes but also management and organizational innovations, this study seeks to (1) discuss the main theoretical and conceptual approaches to innovation, especially management and organizational innovation; (2) understand how the subject has been studied since 1998 by the official innovation survey in Brazil (PINTEC); and (3) examine the evidence presented in three editions of the survey. The results show that innovation involves diverse phenomena and that there is a strong interrelation between technological innovation in products and processes and management and organizational innovations.
\end{abstract}

Keywords

Technological innovation. Organizational innovation. Management innovation.

\section{Introduction}

The so-called innovative activities have been considered essential for sustained economic development in the capitalist system, including the transformation of living standards and the creation of new technologies. However, considering the phenomenon as something complex and diverse, researchers have often had difficulty organizing and reaching a consensus about innovation.

Authors such as Hamel (2007) and Lam (2005) argue that management and organizational innovations are closely related to other types of innovations, such as innovation in products, services and processes. Despite this interrelationship, Lam (2005, p. 138) notes that scholars who study innovation do not "talk" with the ones who study technology innovation. According to the author, this integration should be sought at least on a theoretical level, since in practical terms the phenomenon is subject to different interpretations and demands an integrated approach. Lam (2005) adds that the literature is diverse and not consistently integrated into a theoretical framework.

This diversity is reflected in the profusion of taxonomies for innovation: Technological innovation and non-technological innovations in products and processes, radical and incremental innovation, among others. Notably in the field of management and organization, it is possible to find serious research that deeply examined "management innovation", "managerial innovation", "administrative innovation" and "organizational innovation". Nevertheless, irrespective of nomenclature, it is noted that the focus of this kind of innovation is essentially linked to the creation or adoption of new ways of managing and organizing, which may be or not supported by technology, as this kind of innovation pertains primarily to the social aspects of the organization.

In this perspective, it is essential to seek the understanding of management and organizational innovations in terms of their conceptual and empirical approaches. After all, how do theorists and researchers of innovation and organizational management have addressed the issue? How do these innovations happen in Brazilian companies? What are their relationships with technological innovations in products and processes? To answer these questions, this article aims to (1) discuss the major theoretical and conceptual 
approaches on innovation, particularly on managerial and organizational innovation, (2) understand how the subject has been studied since 1998 by the official survey of innovation in Brazil (Research on Technological Innovation - PINTEC), and (3) examine evidences presented by data from three editions of this research.

The paper is structured as follows: The first section seeks to clarify the situation of the Brazilian context for innovation in general, especially regarding the institutional aspects. Then the concepts and definitions of management and organizational innovation are reviewed and discussed. Subsequently, we present the methodological procedures of research, based on the Brazilian official innovation survey, and the main results for technology, management and organizational innovation. In the last section are the final reflections based on the discussions and findings of the research.

\section{The context of innovation in Brazil}

Various studies are carried out by independent institutes, consulting firms, government agencies, universities, among others, in an attempt to understand innovation. These studies show that innovation is increasingly a concern of government institutions and researchers, besides the productive sector. One of these studies is the research Business Innovation Survey, conducted with Brazilian executives by Strategos (2009) consultancy. The results of this research show, among other things, that there is a clear perception among executives that innovation is essential to the competitiveness of their organizations, although many of them present a lack of cultural roots related to innovation and few of them adopt a structured process of innovation.

In fact, the report by the Institute of Applied Economic Research (INSTITUTO..., 2005) points out that companies and nations develop as they produce, absorb and utilize scientific and technological innovations, especially when the initiatives are encouraged by a national system of innovation and learning. In terms of the national innovation system - the set of institutional actors that interact together to influence the innovative performance of national firms (NELSON, 1993) - since the 1980 decade, Brazil has been implementing some improvements to the fostering of innovation, by the means of tax breaks and sectoral funds.

According to Salerno and Kubota (2008), important tax breaks initiatives for technology development were launched between the 1980s and 1990s, through the Program for Industrial Technological Development (PDTI) and the Program for Technological Development in Agriculture (PDTA), established by specific laws. Furthermore, sectoral funds for research funding were created by the Ministry of Science and Technology (MCT), which also launched the "White Book: Science, Technology, and Innovation" (BRASIL, 2002) with institutional framework guidelines and proposals for the development of science and technology in Brazil. Later, the "Good Law" (Lei do Bem No 11,196/2005) was created in order to improve the government direct financing of research and development, through tax breaks that substituted the incentives of both PDTI and PDTA (SALERNO; KUBOTA, 2008).

Another important step towards encouraging innovation in the Brazilian context was the creation of the federal innovation law (BRASIL, 2004) in October 2005. According to this law, for example, businesses can be incubated in the public space, public and private resources can be shared, financing directed to certain sectors and incentives may be granted. Inasmuch as it establishes these and other rules, this law is directed to a new paradigm of industrialization based on innovation. It is also evident that the federal units, such as the states of Minas Gerais, Bahia, Pernambuco, Mato Grosso and Santa Catarina, are making innovation laws, which have specific mechanisms of incentive.

In the productive sector, innovative activities have been identified in various organizations. The Brazil Innovation Index (IBI) (FURTADO et al., 2007), developed by Unicamp, considered the efforts - qualification of human resources and amounts spent in activities necessary to innovate - and the results of the technological activities of companies - revenues from products and services and propensity for generating patents. According to $\mathrm{BBl}$, (FURTADO et al., 2007) the most innovative organizations in Brazil are Delphi, Embraer, Marcopolo, Silvestre Labs, Vallée, Natura, Brasilata, Faber Castell, Usiminas, Santista, and Granden Rigesa. Furthermore, research conducted by Strategos (2009) found that Petrobras, Embraer and Natura are the Brazilian innovation leaders, according to executives.

Despite the institutional efforts and the companies that actually innovate, Brazil is among the least developed countries ("lagging countries") when considering the variables of a study carried out by MERIT - Maastricht Economic and social Research and training center on Innovation and Technology: innovation drivers, knowledge creation, diffusion, applications and intellectual property (MAASTRICHT..., 2006). This demonstrates the need to develop structural conditions, institutions and other incentive mechanisms to promote innovation effectively, like building a true national system of innovation.

As pointed out by Nelson (1993, p. 13), "[...] nations differ in the mix of industries and these differences alone strongly influence the shape of national innovation systems". Moreover, according to the author, policies and government programs, 
laws and the existence of a common language and a learning culture influence the pace of technological advancement.

It is important to mention positive recent changes in the Brazilian institutional environment that have provided incentives and encouragement for innovators. Among these changes are the creation of the Brazilian Agency for Industrial Development (ABDI), the Productive Development Policy, the 2007-2010 Action Plan, the Law on Biosafety, and the laws of innovation mentioned above.

The Brazilian Technology System (SIBRATEC) is another newly created mechanism to encourage companies to innovate. It is focused on the coordination of various actors in the national innovation system. This mechanism aims to support the technological development of industry and services. SIBRATEC stimulates the formation of sector or thematic networks between the actors of the system, with a focus on the activities of $R \& D$ in innovative processes or products, metrology, technology extension, and technological assistance and transfer.

Despite these changes in the institutional environment, Arbix et al. (2007, p. 27) point out that

[...] the Brazilian government has had historical difficulties to articulate the various agencies and bodies responsible for implementing innovation policies and, in general, need to improve the implementation of innovation policies.

Cassiolato and Lastres (2000, p. 245) indicate that the adoption of "new techniques for organizing the working process" is one of the positive aspects of change in recent years. In order to improve the managerial capabilities of innovative firms, the Financier of Studies and Projects (FINEP) has been a key player in establishing funding programs to promote technological development and innovation in Brazil, such as "Innovate Project" and the "Zero Interest Rate Program”.

Therefore, the attempt to strengthen the management of innovative companies has been a feature of the national innovation system of Brazil, always to support technological innovation in products and processes. However, there are no explicit incentives to the generation of authentic management and organizational innovations, which might be developed to solve managerial and organizational problems case by case.

While this might be "utopia", these innovations can enable an organization to achieve new levels of competitiveness through sustainable competitive advantages based on new routines, resources, dynamic capabilities and skills (LOPES, 2009). Understanding, therefore, the theoretical-conceptual approaches around innovation, particularly in managerial and organizational innovation, is a key step to achieving the objectives of this article.

\section{Innovation: a profusion of concepts in short}

There is an extensive and diverse literature on innovations that occur within organizations, as highlighted by Wolfe (1994), Damanpour (1991), Hage (1999), Birkinshaw, Hamel and Mol (2008), Hamel (2007) and Lam (2005), among others. Many studies seek to understand this phenomenon in a linear way, as evidenced by Damanpour (1991), Wolfe (1994) and Clayton (1997), ignoring temporal and procedural aspects, which prevents researchers reaching solid conclusions. Wolfe (1994) further asserts the lack of consensus among scholars regarding the fact that there is no single theory of innovation. However, according to the author, many of the theories developed are adequate, if applied according to the conditions in which they have been developed.

Often it is necessary to make an analytical cut to distinguish the phenomenon, although this paper does not intend to make a thorough discussion on all theories of innovation, or even about their epistemological or theoretical basis. Wolfe (1994), as an example, says studies on innovation have four main lines: those dealing with the stages of the innovation process, attributes of innovation, organizational contexts and the underlying theoretical perspectives. Despite this conceptual diversity, it is possible to see that the idea of innovation is always linked to the idea of change, novelty.

Thus, this paper brings more comprehensive conceptual perspectives on innovation which may increase the understanding of its fundamentals, and which will help to clearly investigate management and organizational innovation. Unlike the focus of Wolfe (1994) - which reviewed innovation in accordance with its attributes of adaptability, architectural impact, centrality, compatibility, complexity, cost, divisibility, duration, magnitude, visibility, scope, physical properties, degree of novelty, relative advantage, risk, status, and uncertainty - innovation will be highlighted in terms of its more general types.

We can see that the authors focus on innovation in products and services, processes and operations, marketing, strategy, as well as organizational and management innovation (TIDD; BESSANT; PAVITT, 2005; MILES, 2005; TIGRE, 2006; HAMEL, 2007, BIRKINSHAW; HAMEL; MOL, 2008). Damanpour and Schneider (2006, p. 216), for example, define innovation as "[...] the adoption of new product, service, process, technology, policy, structure or administrative system".

In the Oslo Manual (ORGANISATION..., 2005, p. 57), product innovation refers to the "[...] introduction of a new or significantly improved good or service 
with respect to its characteristics or intended uses". These include significant improvements in technical specifications, components and materials, incorporated software, user friendliness or other functional characteristics.

Studies such as the ones from Cerqueira and Carvalho (2002), Andreassi and Bernardes (2007) and the European Commission (2006) defend the differences between service innovation and product innovation. Service innovation is gaining ground due to the growing importance of the service sector to economic development, compared to the industrial sector that emphasizes changes in products and processes.

However, Hamel (2007) points out that the dependence on patent protection and the evolution of technology do not guarantee, in the long run, competitive advantages for organizations that innovate in products or services. According to this author, operational or process innovations also cannot guarantee the elements of sustainable competitive advantage in the long run: this type of innovation rely heavily on the quality of IT infrastructure, on the proprietary benefits derived from outsourcing providers and on the transfer of best practices by consultants.

Another type of innovation is "marketing innovation", which can be understood as the implementation of new marketing methods, significant changes in product designs or packaging, product positioning, promotion, or pricing (ORGANISATION..., 2005, p. 59). A similar concept is shown in PINTEC (INSTITUTO..., 2007, p. 25), in the subsection which refers to "other important strategic and organizational changes".

Innovation in strategy relates to the introduction of new business models that change aspects such as supply chain, value proposition and target customer, according to authors such as Davila, Epstein and Shelton (2007) and Hamel (2007). The IBM Institute for Business Value study, developed by Giesen et al. (2007), reveals that innovation in business models can be divided into three types: industry model, revenue model and business model. However, Hamel (2007) calls attention to the fact that this type of innovation is not so difficult to imitate, as it can be seen in the cases of low-cost airlines and companies that sell computers through the internet, such as Dell.

Some of these different types of innovation and their relations with specific sectors were approached by Pavitt (1984). His work pointed out the differences between the technological trajectories of sectors, especially with regards to the balance between product and process innovation. Supplier dominated sectors - such as agriculture, housing, private services and traditional manufacture - tend to be more innovative in processes. The same happens to scale intensive firms in production intensive sectors, like bulk material (e. g. steel, glass) and assembly (e. g. consumer durables, autos). On the other hand, production intensive firms in sectors with specialized suppliers - such as machinery and instruments - develop more product innovation than process innovation. Finally, science based sectors (e. $g$. electronics, electrical, chemical) tend to be innovative in both product and process innovation.

Supposedly, as it can be seen in the later sections, other types of innovation may cluster sectors differently. Although Pavitt (1984) does not mention other types of innovation in his work, the author acknowledges the relation between firms' "appropriate forms and mixes of skills" and their techniques of production. Nelson and Winter (1982) discuss the importance of the interaction between technological changes and firms.

Their concept of "technological regime" (NELSON; WINTER, 1982, p. 258) differentiated the sciencebased technological regime and the cumulative technology regime, each of which leads sectors to diverse ways of developing innovations. In different technological regimes, the decision to develop an innovation depends on characteristics of the "selection environment" (p. 263), which in turn is influenced by technological change. The authors argue that routines - "all regular and predictable behavioral patterns of firms" (NELSON; WINTER, 1982, p. 14) - are important for the innovative capability development. Changes in routines can also be considered the building blocks of management and organizational innovation as well.

Therefore, it is interesting to clarify the concept of management and organizational innovation, which are the main focus of this paper, in order to better understand the sectoral patterns of innovation. The next section highlights that - unlike innovations in products, services, marketing, processes, operations or strategy - management and organizational innovations should be examined separately, to cover the economic and organizational aspects of the phenomenon.

\section{Management and organizational innovation}

Management and organizational innovation, as a general phenomenon, is mainly related to the creation or adoption of new ways of managing and organizing. According to Hamel (2007, p. 19), "management innovation" means: 
[...] anything that substantially alters the way in which the work of management is carried out [principles and practices], or that significantly modifies customary organizational forms [structures and functions]

in order to improve organization performance. In the same vein, Birkinshaw, Hamel and Mol (2008, p. 825) define management innovation as:

[...] the invention and implementation of a management practice, process, structure or technique that is new to the state of the art and is intended to further organizational goals.

Chandler (1997, p. 48) states that these innovations are related to the development of "[...] new methods and means of coordinating, evaluating and planning the effective use of a wide variety of human, financial and material resources".

In human resource (HR) management, Kossek (1987, p 72) argues that management innovation is related to "[...] programs, policies or practices [perceived as new by organization members] designed to influence attitudes and behaviors of employees". In a similar perspective, Daft (1978, p. 197) defines "[...] administrative innovation" as that related to changes in "recruitment policies, resource allocation, task structuring, authority and rewards". In addition, Stata (1997) relates this type of innovation with the development of new technologies for management: new knowledge, tools and methods that may change, or even revolutionize, the way people manage the business.

Management and organizational innovation can mean many things, as stated by Mikl-Horke (2004, p. 106): “[...] new principles, practices, organizational designs, theories of leadership, or even quasi-philosophical concepts such as the recent six-sigma principle". In his study on the diffusion of such innovation in Central and Eastern Europe, the author states that "a new management philosophy" diffuses quite differently, compared to the diffusion of a new practice or organizational design.

Nickell, Nicolitsas and Patterson (2001, p. 10) point out that management innovation comprises, for example, the reduction of restrictive practices for employees, introduction of a new management technologies, changes in organizational structure towards a more lean one, increased decentralization, new means of managing $\mathrm{HR}$, changes in industrial relations, and the initiation of new practices, such as Just in Time.

Anyway, it is observed that in practice, this innovation includes the typical processes of management, among which may be cited: strategic planning, capital budgeting, project management, hiring and promotion, training and development, internal communications, knowledge management, periodical business reviews, and compensation of employees (HAMEL, 2007, p. 21).

In the Oslo Manual (ORGANISATION..., 2005, p. 61),

[...] the implementation of a new organizational method in business practices of the company [routines and procedures], in the organization of the workplace [distribution of responsibilities and decision-making] or in its external relations [with other firms and institutions]

corresponds to the concept of "organizational innovation". According to the document, such innovation should be considered only when it represents something that has never been used before by the company and when it has been the result of strategic decisions taken by management.

In PINTEC, this type of innovation is investigated using the variable "adoption of advanced management techniques [of production, or environmental information]", "changes in organizational structure" and "[...] new methods of control and management in order to meet standards certification [...]"(INSTITUTO..., 2007, p. 26).

In the line suggested by the Oslo Manual and PINTEC, Tigre (2006, p. 73) defines this type of innovation as

[...] changes that occur in the management structure of the company, in the relation between its different areas, in the expertise of employees, in the relationship with suppliers and customers, and in the multiple techniques of organizing business processes [...]

which the author names "organizational innovation". According to the author, it is this kind of innovation that allows an organization to fit the context, to take advantage of technological innovations.

Pettigrew (2003, p. 334) notes that "[...] more flexible cultures of learning are needed as organizations seek to become more innovative in their forms and processes." In his view, innovation involves changes in processes, structures and boundaries of the firm. Examples of process changes include increased vertical and horizontal interaction, new human resources practices, and integration of information technology. Changes in the structure include the reduction and decentralization of hierarchy levels. Changes in the boundaries of the firm embrace outsourcing and strategic alliances.

In Brazil, Wood Junior (2001) studied the "new organizational configurations" in six Brazilian organizations from different sectors. He found that the understanding of organizational formats is related to improvisation - the configuration can be understood as an ongoing activity, difficult to control. 
Organizations investigated by the author produced deep changes in inter-organizational, organizational and intra-organizational levels.

From the references discussed in this section, Table 1 was built in order to summarize the main conceptual approaches to management and organizational innovation.

The table analysis shows that this kind of innovation is more related to new management knowledge, methods and techniques, policies, practices, processes, and organizational structures. It is also interesting to note the interplay between these approaches: For example, significant changes in philosophy or principles, or even in organizational structure, require new processes and/or new knowledge, methods and techniques of management. Changes in work organization are closely linked to changes in the organizational structure, and so on.

Finally, it is important to distinguish between the generation and the diffusion of management and organizational innovations. The major focus of the literature on management and organizational innovation is more related to diffusion than to generation (HAMEL, 2007). Oliveira (1998), for example, researched the implementation of Total Quality Management - firstly developed at Toyota/ Japan in the 1960s - in a Brazilian textile industry. Birkinshaw, Hamel and Mol (2008) analyze the creation side of management and organizational innovation, arguing that the novelties in this area lead to sustainable competitive advantages. In the same sense, Silva and Plonski (1996) discuss the importance of internal aspects, such as learning, competences and strategic planning, for the reorganization of firms that want to be technologically innovative.

Birkinshaw, Hamel and Mol (2008, p. 831) suggest a four-stage process that involves the organizational and environmental contexts, as well as internal and external agents. The first stage, called motivation,

[...] is concerned with the facilitating factors and precipitating circumstances that lead individuals to consider developing their own management innovation.

In the second phase, invention, the initial act of experimentation occurs, from which a new management practice emerges. Implementation, the next stage, is the process of establishing values in a real environment. Finally, in the last phase, theorizing and labeling, a social process takes place: People inside and outside the organization validate and legitimate the management innovation. Interestingly, Birkinshaw, Hamel and Mol (2008) do not consider diffusion as a stage of the management innovation process.

Thus, without the intention of "closing a concept", when trying to identify different perspectives about what management and organizational innovation is, the conceptual discussion presented here will guide the analysis of the phenomenon proposed in this article, including the "building blocks" for data collection and result analysis, outlined as follows.

Table 1. Conceptual approaches to management and organizational innovation.

\begin{tabular}{|c|c|c|c|c|c|c|c|}
\hline APPROACHES & 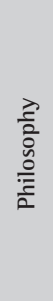 & $\frac{\tilde{e}}{\frac{\tilde{e}}{e}}$ & $\begin{array}{l}\frac{\tilde{U}}{\tilde{O}} \\
\stackrel{0}{0}\end{array}$ & 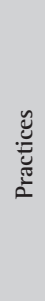 & 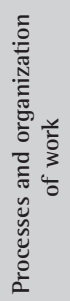 & 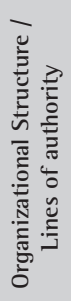 & 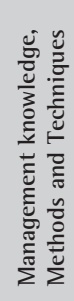 \\
\hline Daft (1978) & & & & & & & \\
\hline Kossek (1987) & & & & & & & \\
\hline Chandler (1997) & & & & & & & \\
\hline Stata (1997) & & & & & & & \\
\hline Nickell, Nicolitsas and Patterson (20 & & & & & & & \\
\hline Wood Junior (2001) & & & & & & & \\
\hline Pettigrew (2003) & & & & & & & \\
\hline Mikl-Horke (2004) & & & & & & & \\
\hline OECD (ORGANISATION..., 2005) & & & & & & & \\
\hline Tigre (2006) & & & & & & & \\
\hline Hamel (2007) & & & & & & & \\
\hline IBGE (INSTITUTO..., 2007) & & & & & & & \\
\hline Birkinshaw, Hamel and Mol (2008) & & & & & & & \\
\hline
\end{tabular}

Source: from the search performed by the authors. 


\section{Method}

The empirical research presented in this article was based on secondary data analysis of innovation surveys. In this kind of analysis, according to Babbie (1999, p. 84), "[...] the findings can be replicated among various subsets of the sample". The replication of a finding "[...] among different subgroups strengthens the certainty that it [the finding] is a general phenomenon in society [...]" (BABBIE, 1999, p. 84). When it comes to research on innovation, despite the potential problems identified by Godinho (2007), Viotti and Macedo (2003), Salazar and Holbrook (2003) and others, this method makes many contributions, for example, to policy making.

The data were collected from the series of the Technology Innovation Survey (PINTEC), for the years 1998-2000, 2001-2003 and 2003-2005 (INSTITUTO..., 2002, 2005, 2007). Each PINTEC edition sets out in detail the methodology, showing strength and high degree of formalization in the production of information on innovation. Its methodology is in line with the Oslo Manual (ORGANISATION..., 2005): According to the Brazilian Institute of Geography and Statistics (IBGE), the

[...] adoption of a methodology accepted and applied internationally, in addition to advanced operating procedures [...] aimed to ensure the quality of information and its comparability with international data (INSTITUTO..., 2007, p. 14).
The reports of PINTEC (INSTITUTO..., 2002, 2005, 2007) describe issues related to: conceptual references, scope of the research (territory and population), timeliness of data, the research unit, classification of economic activities, themes and concepts of variables investigated, aspects of sampling (selection, sampling design, the control sample, estimation), capture and dissemination of information, and rounding and disidentification rules. In the series investigated (INSTITUTO..., 2002, 2005, 2007), the estimated population of companies with ten or more employees were, respectively, 72 thousand, 84.3 thousand and 95.3 thousand, while the samples corresponded to $11,044,11,337$ and 14,334 companies.

In order to demonstrate the relevance of the PINTEC series, a brief summary of the methodological considerations of its latest edition is reported in the following Table 2:

The three PINTEC editions have compatible methodologies, which allows comparability between them in terms of sector classification, the research unit and temporality of three years of data. The main difference between the last edition and previous ones is the inclusion in the former of telecommunications, computer and related services, and research and development sectors.

Survey data can therefore be compared using the variables of capital control origin, company

Table 2. Basic methodological characteristics of PINTEC 2003-2005.

\begin{tabular}{|c|c|}
\hline $\begin{array}{l}\text { Methodological } \\
\text { characteristics }\end{array}$ & Description \\
\hline Universe & $\begin{array}{l}\text { Population of 95,301 entities, in accordance with criteria: } \\
\text { - Companies located in any part of Brazil. } \\
\text { - Organizations with ten or more employees on } 31 \text { December of the reference year of registration data for } \\
\text { selection of the research. } \\
\text { - Companies with active record at the Registrar of Companies (CEMPRE), which covers all entities registered } \\
\text { - Comder a number of CNPJ (National Register of Legal Entities). } \\
\text { divisions of the National Classification of Economic Activities - CNAE } 1.0 \text { (up to } 3 \text { digits). }\end{array}$ \\
\hline Period of research & $\begin{array}{l}\text { - Data for the period of three consecutive years, from } 2003 \text { to } 2005 \text { for the qualitative variables (with no } \\
\text { record of value). } \\
\text { - Data for the year } 2005 \text { for quantitative variables (expenditures and personnel employed in R \& D } \\
\text { expenditures in other innovative activities, the impact of product innovation on sales and exports, etc..) } \\
\text { And some qualitative variables (patents in force and there incomplete projects, for example). }\end{array}$ \\
\hline Research Unit & $\begin{array}{l}\text { - Legal Unit (firm or company) that accounts for the capital invested and that covers all economic activities } \\
\text { carried out in one or more local units address (acting). }\end{array}$ \\
\hline Classification of activities & $\begin{array}{l}\text { - Sectors corresponding to the National Classification of Economic Activities (CNAE 1.0), as follows: mining } \\
\text { and quarrying (C) and Processing Industries (D), Telecommunications (64.2) and Computer and Related } \\
\text { Services (72) and Research and Development (73). }\end{array}$ \\
\hline $\begin{array}{l}\text { Sampling } \\
\text { (in short) }\end{array}$ & $\begin{array}{l}\text { - Sampling of companies that are most likely to be innovative according to different databases, with the } \\
\text { exception of entities in the Research and Development sector, for which the operation was census. } \\
\text { - Independent disproportionate stratification in each final stratum - which varies with the probability of the } \\
\text { entity being or not being groundbreaking, geographical location and economic activity - with probability } \\
\text { of selection proportional to the square root of the number of persons employed. } \\
\text { - Final sample after the application of criteria for obtaining reliable estimates: } \\
\text { - Extractive and transformation industries: } 13,575 \text { companies } \\
\text { - Telecommunications and information technology: } 759 \text { companies } \\
\text { - Research and Development: } 42 \text { entities (census operation) }\end{array}$ \\
\hline
\end{tabular}

Source: compiled from IBGE (INSTITUTO..., 2007). 
sector and size, geographical scope of the company's main market, and other variables directly related to innovation, as in the following Table 3.

For last year's survey, covering the years 2003 to 2005, we requested the IBGE a special tabulation to cross the data of all sampled companies with their data in the Annual Industrial Survey (PIA) in 2005 and Annual Survey of Services (PAS) 2005. We identified those which have at least one management / organizational innovation, therefore, those which responded positively to at least one of the following requirements:

- Implementation of advanced management techniques;

- New devices and tools for managing production;

- New devices and tools for information management;

- New devices and environmental management tools;

- Implementation of significant changes in organizational structure;

- Implementation of new methods of control and management, to meet certification standards (ISO 9000, IS0 14000, QS, TS, OHSAS 18001, SA 800 etc).

To identify the Brazilian companies that did not perform management and organizational innovations between 2003 and 2005, only negative responses to all those requirements were considered.

The crosses required the IBGE to cover the following variables: number of companies, employed persons, total costs (calculated in accordance with the characteristics of such research), net income (net revenue for the industry and net operating income for the service sector), the gross value of production (calculated in accordance with the characteristics of these surveys), costs of operations industrial (industry) or intermediate consumption (services), value of manufacturing (industry) or value added (services).

Finally, in relation to data collection, interviews were conducted face-to-face or by telephone with the

Table 3. Variables directly related to innovation PINTEC.

\section{Variables}

- Introduction of product (or service) technologically new or significantly improved

- Implementation of advanced management techniques

- Implementation of significant changes in organizational structure

- Implementation of new methods of control and management in order to meet certification standards (1SO 9000, 1SO 14000, QS, TS, OHSAS 18001, SA 800 etc..)

- Implementation of significant changes in corporate strategy*

- Significant changes in concepts and marketing strategies*

- Significant changes in aesthetics, design or other subjective changes in at least one of the products*

Source: compiled from IBGE (INSTITUTO..., 2002, 2005, 2007). (*) In spite of conceptual perspectives, the variables of innovation in marketing and strategy were included in the analysis due to the fact that the reports are available only with aggregate data for the category "Other important strategic and organizational changes". support of a computer assisted interview software, depending on the size and location of the organization. The informants were one or more representatives of each company studied, preferably related to innovative activities. To ensure the validity of the survey, the IBGE carried out consistent control sample procedures with the exclusion of inactive or shut down companies in the sectors covered by the design sample and companies that did not provide information.

Reports of the PINTEC series are published on the official website of the IBGE (http://www.ibge.gov. br). From the reports data we prepared proportions analysis related to innovation, as shown in the following sections.

\section{Evolution of rates and patterns of innovation in Brazil}

According to the official innovation survey conducted in Brazilian companies, the proportion of companies that implement innovations in product / process has increased slowly. As the following Table 4 shows, the proportion of innovative Brazilian companies grew from 31.5\% in the late 90 s to $34.4 \%$ in the year 2005.

Data from the series of the survey showed in particular that the companies operating in the manufacturing industries are able to deploy more products or processes new or substantially improved compared to the extractive industries. However, it is noteworthy the fact that companies in the service sector have an innovation rate significantly higher than industrial firms: around 57\% of telecom, IT, and research and development companies made innovations between 2003 and 2005 .

Moreover, the innovation rates vary widely from sector to sector. The data from the 1998-2000 edition, for example, shows that $68 \%$ of companies in the industry of office equipment and computer made innovations in product (or service) and / or process, while only 13\% of companies in the recycling industry carried out these types of innovation. In the variables related to management and organizational innovations, these same industries showed 26\% and $17 \%$ of companies performing other strategic organizational changes.

For the analysis of sector innovation patterns, three graphs are presented below. They cross results of the variables of technological innovation in product and/ or process and aggregate variables in the category "other important strategic and organizational changes". Variables in this category identify innovations in marketing and strategy, the implementation of advanced management techniques, the implementation 
of significant changes in organizational structure and the adoption of new methods of control and management, to meet certification standards such as ISO 9000, ISO 14000, QS, TS, OHSAS 18001, SA 800, among others.

As evidenced in Figure 1, between 1998 and 2000, Brazilian companies were doing other more strategic and organizational changes than technological innovations in products or processes, especially when comparing these data with those from 2001 to 2003 and from 2003 to 2005. Sectors such as clothing and accessories, furniture, textiles and leather products have excelled in other strategic and organizational changes, while the industries of office equipment and computers, consumer electronics and communications, materials and electrical equipment stood in the amount of companies which made technological innovations in products or processes. The recycling sector is highlighted with a low proportion of firms performing both technological innovation and other strategic and organizational changes.

In the second edition of the survey, there was a "greater focus" from Brazilian companies on technological innovation, especially in the industries of office equipment and computers, electronics and communications, with respect to technological innovations. In general, as shown in Figure 2, industries are concentrated both in "technological innovations" and "other strategic and organizational changes" in pursuit of greater competitiveness.

Figure 3 shows, in turn, a move of many sectors toward technological innovation, i.e., a greater

Table 4. Rates of technology innovation in Brazilian companies - by sector - PINTEC 2005.

\begin{tabular}{lccr}
\hline $\begin{array}{c}\text { Selected activities of industry } \\
\text { and services }\end{array}$ & \multicolumn{2}{c}{ Companies that have implemented innovation in product and / or process } \\
\cline { 2 - 4 } & $1998-2000$ & $2001-2003$ & $2003-2005$ \\
\hline Total & $22,698(31.5 \%)$ & $28,036(33.3 \%)$ & $32,796(34.4 \%)$ \\
Extractive lndustries & $297(17.2 \%)$ & $415(22 \%)$ & $427(23.1 \%)$ \\
Manufacturing industry & $22,401(31.9 \%)$ & $27,621(33.5 \%)$ & $29,951(33.6 \%)$ \\
Services & -- & -- & $2,418(57 \%)$ \\
\hline
\end{tabular}

Source: the authors from IBGE (INSTITUTO..., 2002, 2005, 2007).

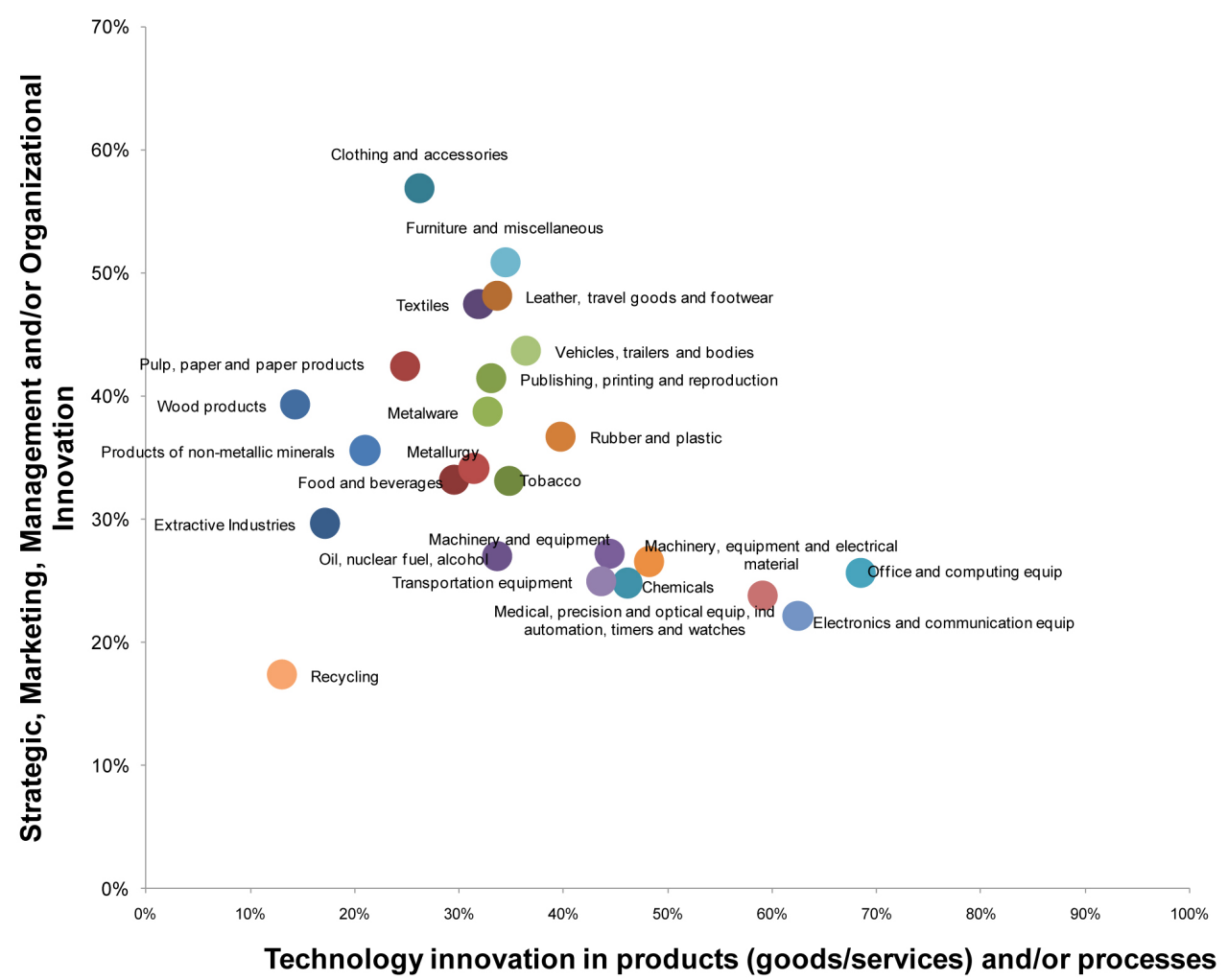

Figure 1. Sectoral patterns of innovation in Brazil - 1998-2000 PINTEC. 
proportion of innovative firms in sectors such as office equipment and computers, consumer electronics and communications, materials and electrical equipment. Innovations in the research conducted between 2003 and 2005 occurred intensively in the medical and precision equipment industry, which stood in the percentage of firms that innovate in products or processes. Moreover, from the third edition, telecommunications, computer and related services, and research and development were included in the sample. These sectors had higher proportion of companies conducting technological innovations rather than just other strategic and organizational changes, especially when compared to most industrial sectors.

The three figures show, therefore, that in Brazil the patterns of technological innovation in products and processes, marketing, strategy, management and organizational differ from sector to sector. At first glance, however, a trend could not be established for each sector, as Brazilian companies sometimes innovated more in products or processes, sometimes performed other types of innovation, as management and organizational innovation - that is, some sectors "progressed" between 2001 and 2003 and "regressed" between 2003 and 2005, depending on the point of view of the reader, as it can be understood from Figure 4 below.

The arrows represent the evolution of sectoral patterns of innovation throughout the years 1998-2000, 2001-2003 and 2003-2005, shown for transportation equipment; medical, precision and optical equipment; industry automation, timers and watches; and wood products, which illustrate sectors with great variability in terms of technological innovation in products and processes and innovations in marketing, strategy, management and organization. Sectors such as office and computing equipment; clothing and accessories; extractive industries; and recycling were plotted in the figure to illustrate that some industries do not vary much in their rate of innovation.

\subsection{Technological innovation in product/ process versus management/organizational innovation}

Based on data from the latest edition of PINTEC, it was possible to verify the relationship between the variables of innovation in products and processes and the variables of management and organizational innovation, as it can be seen in Table 5. According to

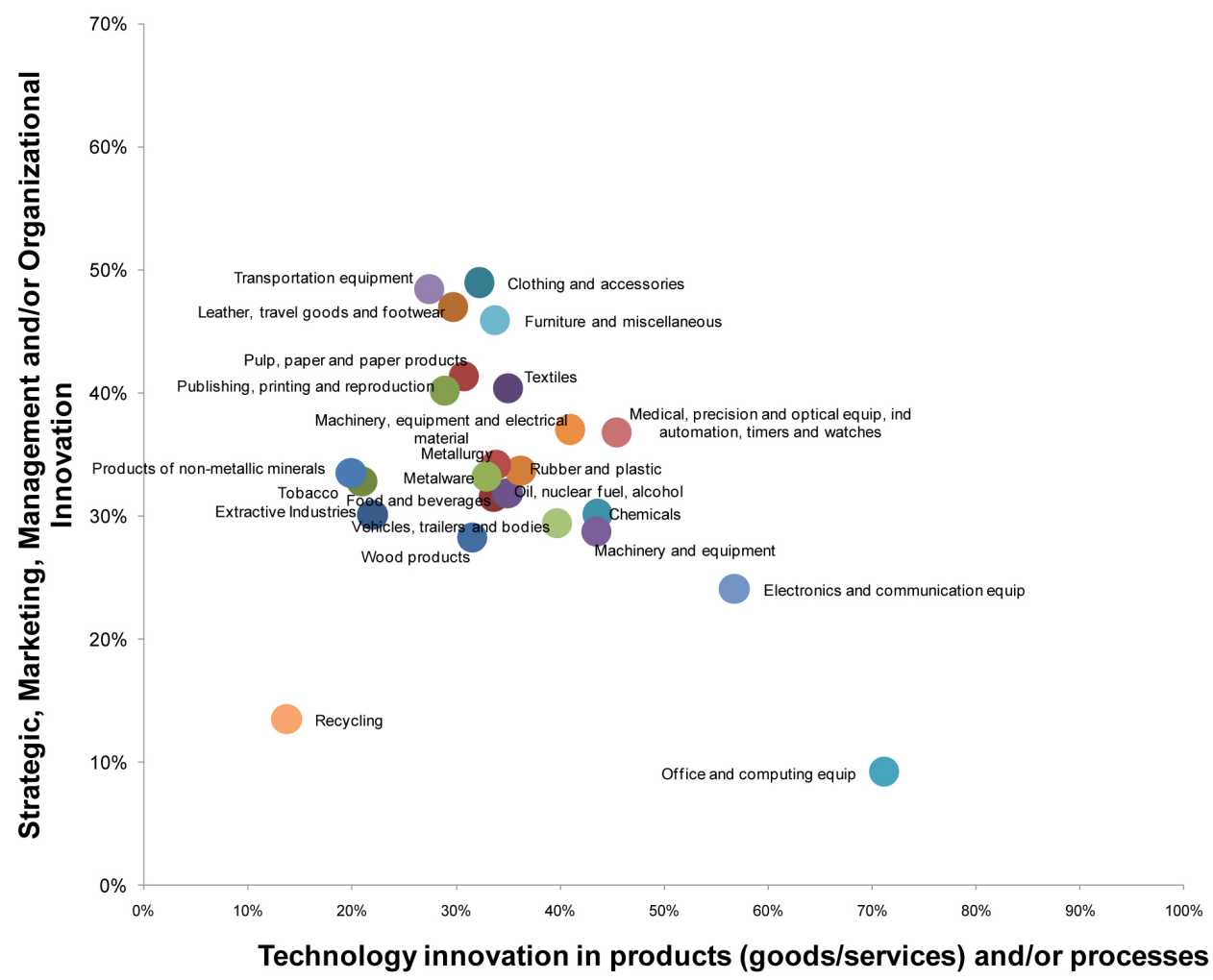

Figure 2. Sectoral patterns of innovation in Brazil - 2001-2003 PINTEC. 


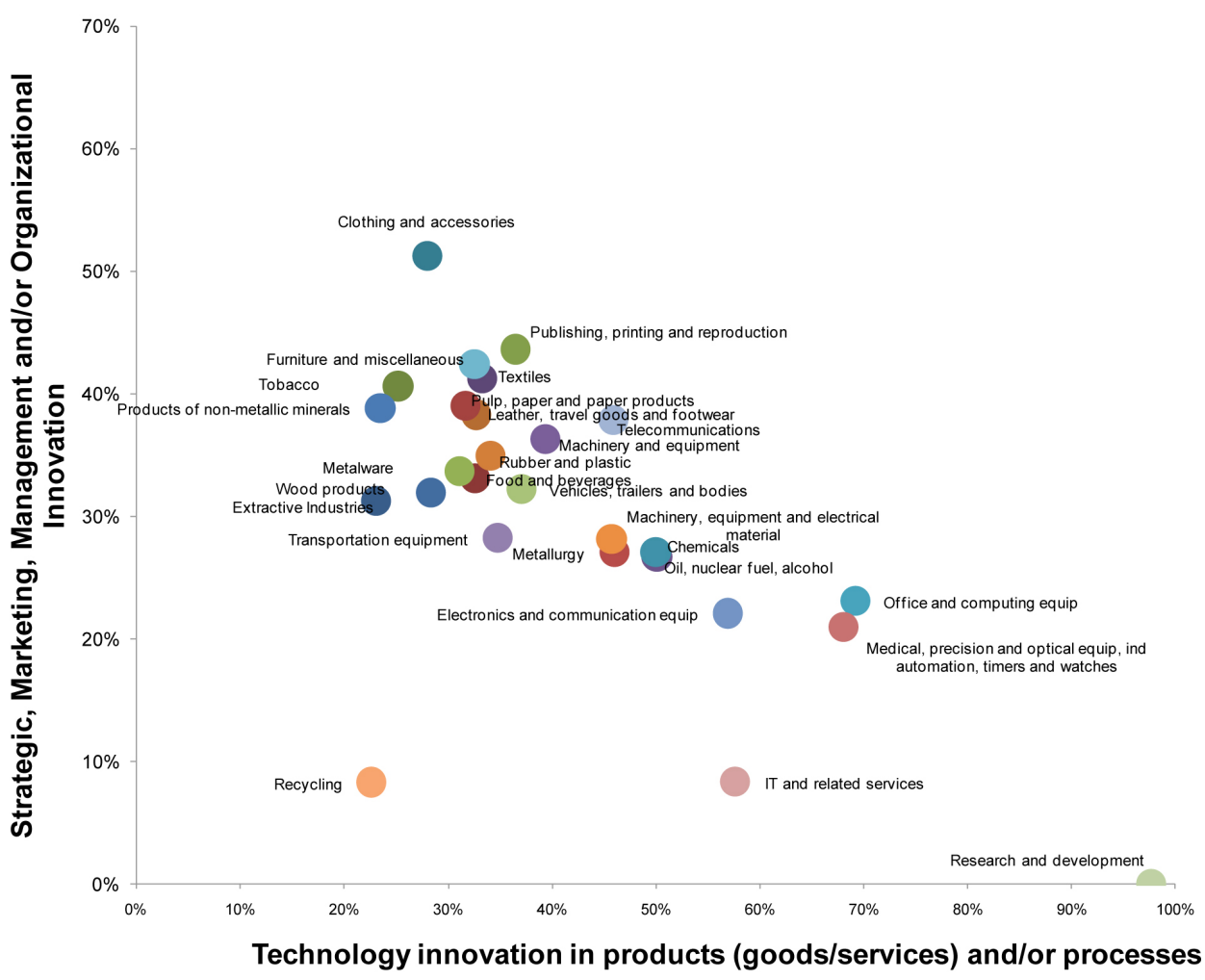

Figure 3. Sectoral patterns of innovation in Brazil - 2003-2005 PINTEC.

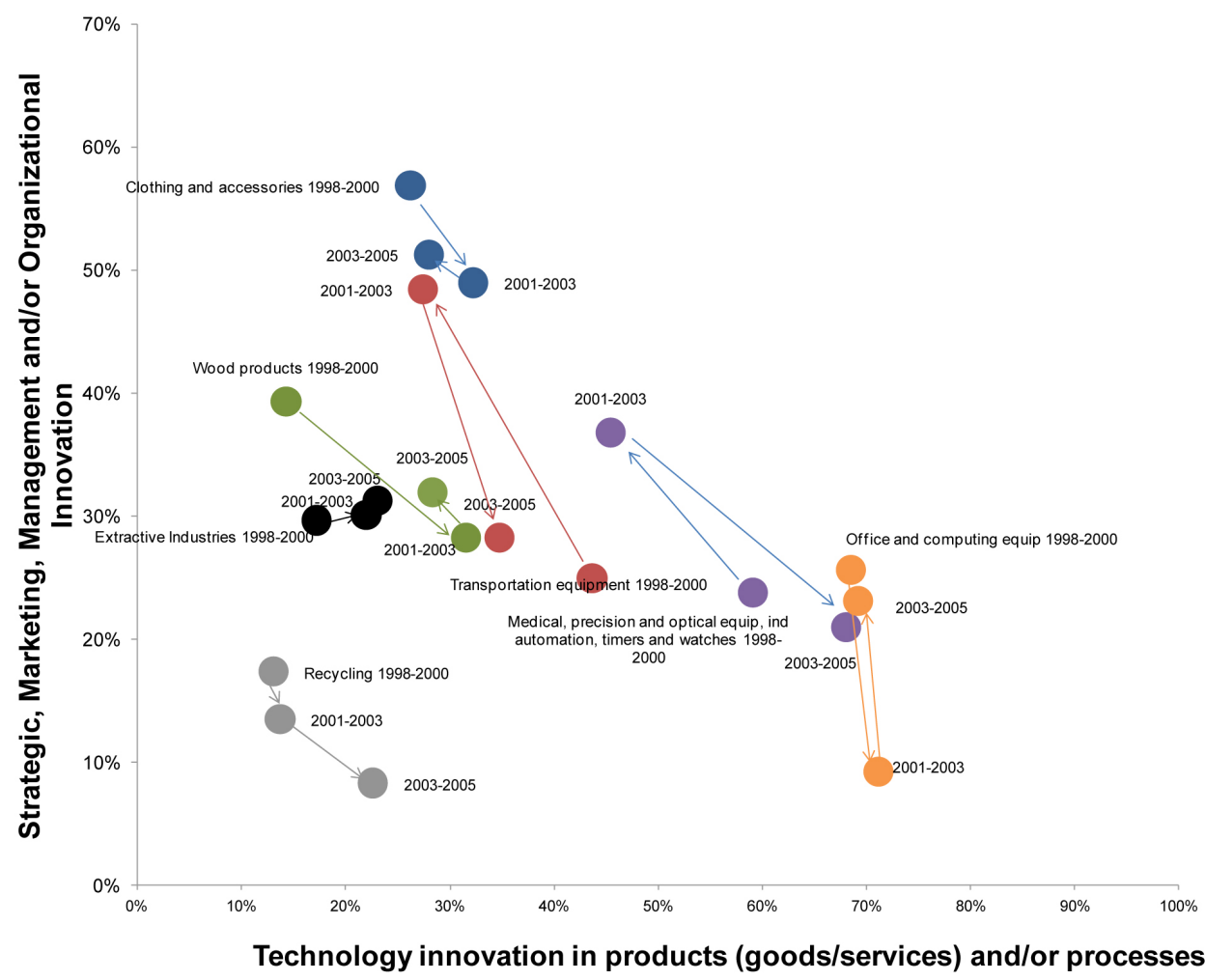

Figure 4. Evolution of sectoral patterns of innovation in Brazil - 1998-2005 PINTEC. 
data obtained from the IBGE (INSTITUTO..., 2007), the set of companies which made innovations in products or services had high rates for the variables related to significant changes in organizational structure and advanced management techniques, compared to companies that did not innovate in products or services. This ratio can also be identified for the companies that innovated in process and for that innovated in both management and organization concurrently.

The positive answers to the variable concerning implementation of advanced management techniques stand out against the other variables, with at least $40 \%$ for innovative companies. For example: from the Brazilian companies that innovate in product, $41 \%$ have implemented advanced management techniques. Furthermore, a greater discrepancy was found between the percentage of innovative product and/or process companies that have implemented these techniques and the percentage of "not innovative" ones that implemented them.

On the other hand, only $17 \%$ of the companies that innovated in processes also made the implementation of new methods of control and management to meet certification standards. Nevertheless, this rate is higher than the one from companies that did not innovate in process and have implemented these methods (8\%).

Finally, this Table 5 shows, in general, that the incidence of management and organizational innovations is greater in companies that are innovative in products or processes (or both). Nevertheless, it is not possible to establish a causal relationship between them, although several authors argue that the organizational and management innovations constitute the basis for technological innovations.

\subsection{Creation of value and management and organizational innovation}

According to data from special tabulation obtained from the IBGE (INSTITUTO..., 2007), referred to data from the third edition of PINTEC, those companies that performed management and organizational innovations accounted for 43\% of 95,301 Brazilian firms between 2003 and 2005. This ratio is the same for firms in the industry sector (it is noted that most firms surveyed belong to this group of economic activities, a fact that influences the general recorder). However, when analyzing the service sector separately, the percentage of companies that innovated was a little higher: about $47 \%$.

The following Table 6 characterizes the proportion of companies which made at least one management/ organizational innovation in relation to the number of persons employed and the number of companies.

Because of the variation in the size of the companies (number of persons employed) it is important to realize that those which had at least one management/organizational innovation covered 67\% of employed persons. Among the group of economic activities, companies in extractive industries that have done this kind of innovation took 71\% of employed persons in this group, while the manufacturing industry and services accounted for 66\% and 59\% of employed persons, respectively.

The data presented in Table 6 can serve as a parameter for the analysis of other variables PIA Company and PAS Services, whose details are presented in Table 7 below. If compared to the results of employed persons (between 59\% and 71\%) and number of companies (between 43\% and 47\%) for groups of economic activities presented in this table, the results for the other variables of the PIA Company and PAS Services showed relatively higher for those that have at least one management/organizational innovation (between 74\% and 88\%).

Table 7 shows that the Brazilian companies that had at least one management/organizational innovation are responsible for: $84 \%$ of the total net revenue and the gross value of production, for $83 \%$ of the industrial operations or intermediate

Table 5. Relationship between innovation in product / process innovation and management / organizational innovation PINTEC 2005.

\begin{tabular}{|c|c|c|c|c|c|c|c|}
\hline \multirow{2}{*}{ Selected variables } & & \multicolumn{2}{|c|}{$\begin{array}{l}\text { lnnovation in product } \\
\text { (goods or services) }(\%)\end{array}$} & \multicolumn{2}{|c|}{$\begin{array}{l}\text { Innovation } \\
\text { process }(\%)\end{array}$} & \multicolumn{2}{|c|}{$\begin{array}{l}\text { Innovation in product } \\
\text { and process }(\%)\end{array}$} \\
\hline & & Yes & No & Yes & No & Yes & No \\
\hline \multirow{2}{*}{$\begin{array}{l}\text { Implementation of significant changes in } \\
\text { organizational structure }\end{array}$} & Yes & 38 & 21 & 35 & 21 & 38 & 19 \\
\hline & No & 62 & 79 & 65 & 79 & 62 & 81 \\
\hline \multirow{2}{*}{$\begin{array}{l}\text { Implementation of new methods of control and } \\
\text { management in order to meet certification standards }\end{array}$} & Yes & 19 & 9 & 17 & 8 & 19 & 7 \\
\hline & No & 81 & 91 & 83 & 92 & 81 & 93 \\
\hline \multirow{2}{*}{ Implementation of advanced management } & Yes & 41 & 19 & 40 & 17 & 43 & 15 \\
\hline & No & 59 & 81 & 60 & 83 & 57 & 85 \\
\hline
\end{tabular}

Source: Special tabulation IBGE, Coordination of Industry, Technological Innovation Survey 2005. 
Table 6. Groups of economic activities, employed persons and number of companies with at least one management/organizational innovation - PINTEC, PIA and PAS 2005.

\begin{tabular}{|c|c|c|c|c|}
\hline \multirow[b]{2}{*}{$\begin{array}{l}\text { Selected activities of } \\
\text { industry and services }\end{array}$} & \multicolumn{2}{|c|}{ Number of companies } & \multicolumn{2}{|c|}{ Employed persons } \\
\hline & $\begin{array}{l}\text { Performed management / } \\
\text { organizational innovation }\end{array}$ & $\begin{array}{c}\text { Did not perform } \\
\text { management / } \\
\text { organizational innovation }\end{array}$ & $\begin{array}{l}\text { Performed management / } \\
\text { organizational innovation }\end{array}$ & $\begin{array}{c}\text { Did not perform } \\
\text { management / } \\
\text { organizational innovation }\end{array}$ \\
\hline Total & $41,256(43 \%)$ & $54,044(57 \%)$ & $4,239,084(67 \%)$ & $2,103,070(33 \%)$ \\
\hline Extractive Industries & $814(44 \%)$ & $1,036(56 \%)$ & $82,524(71 \%)$ & 34,207 (29\%) \\
\hline Manufacturing industry & $38,456(43 \%)$ & $50,749(57 \%)$ & $3,917,842(66 \%)$ & $2,005,300(34 \%)$ \\
\hline Services & $1,987(47 \%)$ & $2,259(53 \%)$ & $238,719(59 \%)$ & $63,563(41 \%)$ \\
\hline
\end{tabular}

Source: Special tabulation IBGE, Coordination of Industry, Technological Innovation Survey 2005.

Table 7. Groups of economic activities and results for companies that had at least one management/organizational innovation - PINTEC, PIA and PAS 2005.

\begin{tabular}{|c|c|c|c|c|c|}
\hline \multirow{2}{*}{$\begin{array}{c}\text { Selected } \\
\text { activities of } \\
\text { industry and } \\
\text { services }\end{array}$} & \multicolumn{5}{|c|}{ Results for those that have managerial and organizational innovations } \\
\hline & $\begin{array}{l}\text { Total Costs } \\
\text { (1000 U.S. \$) }\end{array}$ & $\begin{array}{l}\text { Net Sales or Net } \\
\text { Operating } \\
(1000 \text { U.S. } \$)\end{array}$ & $\begin{array}{l}\text { Gross Value of } \\
\text { Production } \\
\text { (1000 U.S. \$) }\end{array}$ & $\begin{array}{l}\text { Cost of Industrial Operations } \\
\text { and Intermediate consumption } \\
(1000 \text { U.S. \$) }\end{array}$ & $\begin{array}{l}\text { Industrial Manufacturing } \\
\text { Value or Value Added } \\
\text { (1000 U.S. \$) }\end{array}$ \\
\hline Total & $\begin{array}{c}1,117,377,657 \\
(84 \%)\end{array}$ & $\begin{array}{c}1,143,954,587 \\
(84 \%)\end{array}$ & $\begin{array}{c}1,083,304,317 \\
(84 \%)\end{array}$ & $\begin{array}{c}609,306,842 \\
(83 \%)\end{array}$ & $\begin{array}{c}473,997,475 \\
(85 \%)\end{array}$ \\
\hline $\begin{array}{l}\text { Extractive } \\
\text { Industries }\end{array}$ & $\begin{array}{c}26,707,465 \\
(84 \%)\end{array}$ & $\begin{array}{c}32,439,062 \\
(86 \%)\end{array}$ & $\begin{array}{c}29,240,785 \\
(85 \%)\end{array}$ & $\begin{array}{c}9,785,922 \\
(79 \%)\end{array}$ & $\begin{array}{c}19,454,863 \\
(88 \%)\end{array}$ \\
\hline $\begin{array}{l}\text { Manufacturing } \\
\text { industry }\end{array}$ & $\begin{array}{c}986,325,989 \\
(83 \%)\end{array}$ & $\begin{array}{c}998,910,231 \\
(83 \%)\end{array}$ & $\begin{array}{c}948,729,914 \\
(83 \%)\end{array}$ & $\begin{array}{c}545,258,663 \\
(82 \%)\end{array}$ & $\begin{array}{c}403,471,251 \\
(84 \%)\end{array}$ \\
\hline Services & $\begin{array}{c}104,344,204 \\
(74 \%)\end{array}$ & $\begin{array}{c}112,605,294 \\
(75 \%)\end{array}$ & $\begin{array}{c}105,333,619 \\
(75 \%)\end{array}$ & $\begin{array}{c}54,262,257 \\
(75 \%)\end{array}$ & $\begin{array}{c}51,071,362 \\
(74 \%)\end{array}$ \\
\hline
\end{tabular}

Source: Special tabulation IBGE, Coordination of Industry, Technological Innovation Survey 2005.

consumption and 85\% of the value of manufacturing or value added.

In relation to extractive industries, companies that have at least one management/organizational innovation are responsible for $84 \%$ of the total, $86 \%$ of net sales, $85 \%$ of the gross value of production, $79 \%$ of costs industrial operations and $88 \%$ of the value of manufacturing. These data are high when compared to the fact that $44 \%$ of companies in this group of activities carried out such innovations, accounting for $71 \%$ of employed persons.

The data from manufacturing industries show that firms with at least one management / organizational innovation are responsible for 83\% of the total of net sales and gross value of production, for $82 \%$ of the industrial operations and $84 \%$ of the value of manufacturing. Just as in the extractive industries, such data is superior when compared to the fact that $43 \%$ of companies in this group of activities carried out such innovations, accounting for 66\% of employed persons.

In the service sector, where $47 \%$ of companies made at least one management/organizational innovation, representing 59\% of employed persons, they were responsible for 74\% of the total costs, $75 \%$ of net operating income, $75 \%$ of the gross value of production, $75 \%$ of intermediate consumption and $74 \%$ of value added.
Therefore, these results show that the added value is higher in Brazilian companies that made at least one management/organizational innovation between 2003 and 2005, when one compares the representativeness of the companies surveyed with the criteria of value added vis a vis their representativeness in terms of employed persons and number of companies.

\section{Conclusions}

Based on the discussions above, some findings become evident. The first relates to the different definitions of innovation, especially when it comes to management and organizational innovations. Note that this is a typical conceptual diversity of relevant topics that are still able to generate debate in academia. Researchers should adhere to these definitions to define the type of innovation under investigation.

Considering this wealth of concepts and classifications, it became necessary to delineate the perspective from which these types of innovation were investigated. We could say that management innovations and organizational innovations involve new management knowledge, methods, techniques, policies, practices, processes and organizational structures, although different definitions of these types of innovation have been discussed. 
Empirical evidence shows that the changes made by companies may be perceived as an internal adjustment to cope with the requirements of competitiveness. Nevertheless, there is no evidence in the data from PINTEC that innovative companies have either adopted or created them over the years. PINTEC does not investigate this issue for management and organizational innovations as it does for innovations in goods, services and processes.

In fact, innovations in products, services or processes are important for maintaining or increasing the competitiveness of a business, reflecting on the competitiveness of sectors and nations - certainly competitiveness depends on other factors such as industry structure, demand conditions, skilled labor, infrastructure, structural and systemic factors.

Without going into all the factors of competitiveness, there was clear evidence that Brazilian companies with innovative activities also developed management and organizational innovations. Arising from that conclusion, some questions could lead to a more precise analysis of how the phenomenon occurs in Brazilian organizations: do the changes in the management and organization spur technological innovation, or the opposite? Does the former demanded significant changes in organizational structure, implementation of new systems of knowledge management, among other variables investigated? The data provided in reports from PINTEC failed to answer these questions.

The effort of Brazilian companies towards technological innovations has been found and may be related to changes in the Brazilian context. The changes discussed in this article might have stimulated the growing rates of innovation. In fact, innovation systems are important for the innovative capacity of organizations and economies as a whole. However, in Brazil, such changes are directed mainly to support technological innovations in products or processes.

The improvement of the national innovation system could, together with other factors, enable Brazilian organizations to achieve new levels of national and international competitiveness based on management and organizational innovation.

Therefore, these considerations have implications for the formation of public policies which encourage organizations to develop solutions to their own managerial and organizational problems. A bottom line question would be: Would the incentives be aimed at the diffusion of this type of innovation or at the creation or generation of novelties in the field of management and work organization?

Regardless of this issue, the Brazilian organizations have realized that performing management and organizational innovations, as well as technological innovations, is an interesting path to better their performance in an increasingly competitive environment. The question is whether the path can also "walk through" the process of creating original forms of managing and organizing. From the empirical point of view, this was a limitation of this study, since PINTEC is not designed to capture detailed data on management and organizational innovation.

Despite this limitation, we suggest future studies that can examine PINTEC micro-data, keeping, of course, their confidentiality. Data could be investigated with descriptive statistics, regarding the relationships between "other important strategic and organizational changes" variables and other ones, such as those referring to "innovation in product and/or process". One could infer, for example, that organizations perform management/organizational innovation to innovate in products/processes.

\section{REFERENCES}

ANDREASSI, T.; BERNARDES, R. (Org.). Inovação em Serviços Intensivos em Conhecimento. São Paulo: Saraiva, 2007.

ARBIX, G. et al. Projeto Metodologia para Conceber e Executar Plano de Mobilização Brasileira pela Inovação Tecnológica - MOBIT (report). São Paulo: ABDI/IEA USP, 2007.

BABBIE, E. Métodos de Pesquisa de Survey. Belo Horizonte: Editora UFMG, 1999.

BIRKINSHAW, J.; HAMEL, G.; MOL, M. Management innovation. Academy of Management Review, v. 33, n. $4, \quad 825-845, \quad 2008$. http://dx.doi.org/10.5465/ AMR.2008.34421969

BRASIL. Ministério de Ciência e Tecnologia - MCT. Livro Branco: Ciência, Tecnologia e Inovação. Brasil: MCT, 2002.

BRASIL. Ministério de Ciência e Tecnologia - MCT. Lei $n^{\circ} 10.973$, de 02 de dezembro de 2004. Dispõe sobre incentivos à inovação e à pesquisa científica e tecnológica no ambiente produtivo e dá outras providências. Diário Oficial da República Federativa do Brasil, Brasília, DF, dez. 2004. Disponível em: <http://www.planalto.gov.br/ ccivil_03/_ato2004-2006/2004/Lei/L10.973.htm>.

CASSIOLATO, J.; LASTRES, H. Sistemas de inovação: Políticas e Perspectivas. Parcerias estratégicas, v. 5, n. 8, p. 237$255,2000$.

CERQueira, A. H. F.; CARVAlHO, R. Q. Sociedade PósIndustrial: A Inovação no Setor de Serviços. In: SIMPÓSIO DE GESTÃO DA INOVAÇÃO TECNOLÓGICA, 12., 2002, Salvador. Anais... Salvador: PGT/USP, 2002.

CHANDLER, A. D. Strategy and Structure. In: FOSS, N. J. (Org.). Resources Firms and Strategies - A Reader in the Resource-Based Perspective. Oxford: Oxford University Press, 1997.

CLAYTON, P. Implementation of Organizational Innovation: Studies of Academica Research Libraries. San Diego: Academic Press, 1997.

DAFT, R. L. A dual-core model of organizational innovation. Academy of Management Journal, v. 21, n. 2, p. 193210, 1978. http://dx.doi.org/10.2307/255754 
DAMANPOUR, F. Organizational innovation: a meta-analysis of effects of determinants and moderators. Academy of Management Journal, v. 34, n. 3, p. 555-590, 1991. http://dx.doi.org/10.2307/256406

DAMANPOUR, F.; SCHNEIDER, M. Phases of the Adoption of Innovation in Organizations: Effects of Environment, Organization and Top Managers. British Journal of Management, v. 17, p. 215-236, 2006. http://dx.doi. $\operatorname{org} / 10.1111 / j .1467-8551.2006 .00498 . x$

DAVILA, T.; EPSTEIN, M. J.; SHELTON, R. As regras da inovação. Porto Alegre: Bookman, 2007.

EUROPEAN COMISSION. EUR 21959 - The future of $R \& D$ in services: implications for EU research and innovation policies. Luxembourg: Office for Official Publications of the European Communities, 2006.

FURTADO, A. et al. IBl: o ranking das empresas. Inovação Uniemp, v. 3, n. 3, jun. 2007.

GIESEN, E. et al. Paths to success: Three ways to innovate your business model. IBM Institute for Business Value, 2007.

GODINHO, M. M. Indicadores de C\&T, inovação e conhecimento: onde estamos? Para onde vamos? Análise Social, v. 42, n. 182, p. 239-274, 2007.

HAGE, J. T. Organizational innovation and organizational change. Annual Reviews of Sociology, p. 597-622, 1999. http://dx.doi.org/10.1146/annurev.soc.25.1.597

HAMEL, G. The Future of Management. Boston: Harvard Business School Publishing, 2007.

INSTITUTO BRASILEIRO DE GEOGRAFIA E ESTATÍSTICA - IBGE. Pesquisa Industrial de Inovação Tecnológica - Pintec 2000. Rio de Janeiro: IBGE, 2002.

INSTITUTO BRASILEIRO DE GEOGRAFIA E ESTATISTICA - IBGE. Pesquisa Industrial de Inovação Tecnológica - Pintec 2003. Rio de Janeiro: IBGE, 2005.

INSTITUTO BRASILEIRO DE GEOGRAFIA E ESTATÍSTICA - IBGE. Pesquisa Industrial de Inovação Tecnológica - Pintec 2005. Rio de Janeiro: IBGE, 2007.

INSTITUTO DE PESQUISA ECONÔMICA APLICADA - IPEA. Brasil: o Estado de uma Nação. IPEA, 2005.

KOSSEK, E. E. Human Resources Management Innovation. Human Resource Management, v. 26, n. 1, p. 7192, 1987. http://dx.doi.org/10.1002/hrm.3930260105

LAM, A. Organizational innovation. In: FAGERBERG, J.; MOWERY, D. C.; NELSON, R. R. The Oxford Handbook of Innovation. Oxford: Oxford University Press, 2005.

LOPES, D. P. T. Inovação em gestão e em formatos organizacionais: um estudo em Organizações brasileiras e portuguesas. 2009. Dissertação (Mestrado)-Universidade Federal de Minas Gerais, Belo Horizonte, 2009.

MAASTRICHT ECONOMIC AND SOCIAL RESEARCH AND TRAINING CENTRE ON INNOVATION AND TECHNOLOGY - MERIT. Global Innovation Scoreboard. Merit, European Trend Chart on Innovation, 2006.

MIKL-HORKE, G. Globalization, transformation and the diffusion of management innovations. Journal for East European Management Studies, v. 9, n. 2, p. 98122,2004

MILES, 1. Innovation in services. In: FAGERBERG, J.; MOWERY, D. C.; NELSON, R. R. The Oxford Handbook of Innovation. Oxford: Oxford University Press, 2005.
NELSON, R. National Innovation Systems: A Comparative Analysis. New York: Oxford University Press, 1993.

NELSON, R.; WINTER, S. G. An evolutionary Theory of Economic Change. Cambridge: Harvard University Press, 1982.

NICKELL, S.; NICOLITSAS, D.; PATTERSON, M. Does Doing Badly Encourage Management Innovation? Oxford Bulletin of Economics and Statistics, v. 63, n. 1, p. 5-28, 2001. http://dx.doi.org/10.1111/14680084.00207

ORGANISATION FOR ECONOMIC CO-OPERATION AND DEVELOPMENT - OECD. Manual de Oslo: diretrizes para coleta e interpretação de dados sobre inovação. 3. ed. FINEP/OECD, 2005.

OLIVEIRA, S. A Vivência da Implantação do Programa de Qualidade Total: Um Estudo de Caso. Produção, v. 8, n. 1, p. 17-28, 1998. http://dx.doi.org/10.1590/S010365131998000100002

PAVITT, K. Sectoral Patterns of Technological Change: Toward a Taxonomy and a Theory. Brighton: Science policy Research Unit - SPRU, University of Sussex, 1984.

PETTIGREW, A. M. Innovative Forms of Organizing: Progress, Performance and Process. In: PETTIGREW, A. M. et al. (Org.). Innovative Forms of Organizing: International Perspectives. London: Sage, 2003. http://dx.doi. org/10.4135/9781446219386.n14

SALAZAR, M., HOLBROOK, A. A debate on innovation surveys. SPRU, University of Sussex, 2003. p. 12-15. Trabalho apresentado à Conferência em Memória de Keith Pavitt What do we Know about Innovation.

SALERNO, M. S.; KUBOTA, L. C. Estado e inovação. In: DE NIGRI, J. A.; KUBOTA, L. C. (Orgs.). Politicas de Incentivo à Inovação Tecnológica. Brasília: IPEA, 2008.

SILVA, J. C. T.; PLONSKI, G. A. Inovação tecnológica: desafio organizacional. Produção, v. 6, n. 2, p. 183-193, 1996.

STATA, R. Aprendizagem organizacional: a chave da inovação gerencial. In: STARKEY, K. (Org.). Como as organizações aprendem: relato do sucesso das grandes empresas. São Paulo: Futura, 1997.

STRATEGOS. Business Innovation Survey - 2009-2010. Strategos/Exame, 2009.

TIDD, J.; BESSANT, J.; PAVITT, K. Managing innovation: Integrating technological, market, and organizational change. 3rd ed. Chichester: John Wiley \& Sons Ltd, 2005.

TIGRE, P. B. Gestão da Inovação: a economia da tecnologia no Brasil. Rio de Janeiro: Elsevier, 2006.

VIOTTI, E. B.; MACEDO, M. M. (Org.). Indicadores de Ciência, Tecnologia e Inovação no Brasil. Campinas: Editora Unicamp, 2003.

WOLFE, R. Organizational innovation: review, critique and suggested research directions. Journal of Management Studies, v. 31, n. 3, p. 405-431, 1994. http://dx.doi. org/10.1111/j.1467-6486.1994.tb00624.x

WOOD JUNIOR, T. Novas configurações organizacionais: pesquisa exploratória empírica sobre organizações locais (research report). São Paulo: EAESP/FGV, 2001. 